\title{
Borrowing As A Tool To Fill The Ideological Thoughts: The Role Of Code-Mixing In An American Brat By Bapsi Sidhwa And The Escape By Qaisra Shiraz
}

\author{
Mirza Noman Shamas \\ Department of English Language and Literature, University of Lahore Gujrat Campus \\ mnomans761@gmail.com \\ Zobia Ehsan \\ Department of English Language and Literature, University of Lahore Gujrat Campus \\ zobiaehsan@gmail.com
}

\begin{abstract}
This research article highlights the temperament, inference, scope, and motives of code mixing in Pakistani English works. One novel from Pakistani English novels namely, An American Brat by Bapsi Sidhwa and one short story namely, The Escape by Qaisra Shehraz are being selected as an illustration of this reading. In this novel and short story the writers have already dealt with the characteristics of post colonialism. English language and literature pierced into the privileged civilizations of the sub-continent, after the end of British Imperialism. Pakistani writers in English are the best interpreter of the post-colonial communal language. In this study, I have hit upon code mixing in English works written by Pakistani authors to a bigger echelon. These works are paragons of arts and the unbelievable mixture of rhetorical and fictitious study. In these works the writers have not abased the confined diversities. They have tinted the value of Pakistani English in order to achieve the chatty desires of native people. These borrowings from the native languages are used to fill the lexical fissures of ideological thoughts. The reason of these borrowings is not to represent the English as substandard assortment. Through the utilization of native words we conclude that the significance of native languages has been tinted to question mark the dialect as well. The words of daily use also have an area of research for English people without having any substitute in English. That's why in English literature innovative practices and ideas of code-mixing have been employed.
\end{abstract}

Key Words: Code-mixing, Urdudized Words, Hybridism, Bilingualism and Multilingualism

\section{Introduction}

Afterwards the severance of sub-continent, English was used like the bureaucrat language in order to disregard Urdu-Bengali controversy. Bapsi sidhwa (1993) describes her own understanding by stressing her attitude towards the status of foreign English Language in Pakistan. She states that her usage of English in writing her novels has not been critically questioned in Pakistan. Devoid of putting in numerous words, it is acknowledged that because of British colonization English is with us to stay, and either we like it or not it has developed into a 
valuable tool: a resource of communication with the rest of the world, and together with Urdu, a link, elitist if $\mathrm{u}$ will, among people who speak diverse languages within country.

Qaisra Shahraz is a popular and praised Pakistan-born and Manchester- resident writer. She has won the National Diversity "Lifetime Achiever" reward for her educational and literary services. She has also toiled as a member of the Royal society of arts. She has also worked as a counselor to Asia Pacific writers and Translators organizations. In her short story "The Escape", she also used code-mix words from her own national country. She also used many words of Urdu language in her short story in order to influence her own national language because she was a Diaspora and had dispersed personality. So it was difficult for her to ignore her own country and the country of luxuries. That's why she mostly switches form one language (English) to other language (Urdu).

The utilization of single language into new language between the similar statements, whether it is in verbal or printed form is known as code-mixing. Now days, the use of multiple languages in many cultures is the most common factor. Code mixing helps to comprehend the utilization of language, its purpose and nature of the relationship between individual values in a socio-cultural perspective. A code is meant to be a language technique or miscellany in the language and it is altering an element of information in communiqué just like, a letter or word phrase. At the same time, the usage of two different diversities in a speech, or usage of one language into other language is known as code-mixing. The orator or the author does not unearth appropriate appellations in the manifest language, so they employ a lot of locutions from their native tongue to overcome this problem. Sometimes Code-mixing refers to the hybridization of language; it means that it constructs the issues related to Language maintenance then causes for a language shift and at last demise. So, code-mixing is intrapersonal.

Bilinguals use code-mixing in their routine life. The characters and speech communities in Pakistani English works are the representative of this specimen. Afterwards the liberty of Pakistan, English-literature that had been produced by Pakistani writers was postcolonial literature in nature and in fact it was a response to the colonial Literature as well. The use of Urdu words is prominent in the writings of all Pakistani English writers, because they considered Urdu Language as the most prestigious Language in their works at the secondary level. The usage of appellations from the native tongue mechanically fused in the second Language in the writings of every writer as a common practice. In order to show the cultural practices and conventions, every writer uses code-mixing in his writings.

The new dimensions have been explored by a lot of researchers in order to highlight the life like activities of native with respect to their expressive culture and local languages. On the foundation of this aspect, the main objective of this manifesto is to demonstrate that code-mixing is an account of ethnicities and morals at the higher-level but not at the lower-level. This research article represents the exploration of the changes in Languages with respect to fidelity and bi-dialectal, because language plays a very important part in culture. Language covers the means to discover code-mixing in correlation to philology that how the language gaps and domains, societal factors and basic factors, physical settings and stylistic motivations have been provoked as penalties of code mixed speeches. The awareness of the readers with the writer and 
admiration of cultures is the main task of code mixing. Moreover a different variety of English is the result of Post-colonial state.

In order to visible the culture of motherland Chinua Achebe has also mixed numerous appellations of African language in English and same is a case with Pakistani writers in their writings which will be considered in this research article. This research article also emphasis on the edifying and societal discrepancies by language with respect to code-mixing which overlay a technique for the canvasser to categorize along with customs by giving the impression of being mixed language. The Postcolonial literature gives more value to language as in the code-mixing; it got innovative means to signify the breakdown of lexical terminology. In postcolonial literature, Language is most apparent because colonized writers accept it as an approach to save empires and communal significances from the alien authority. The usage of local words from native language increases the awareness and association of readers as well.

This research paper concentrates on two literary pieces written by Pakistani writers, in which the malfunction of glossary in English is being manifested by native words from Urdu lexicons. The research study will also discover the endeavor of these two Pakistani writers in their literary pieces with respect to code-mixing is and will also highlight that to what extent they used it in their works as well. This research study will emerge questions for code-mixing in these two works that are:

1. How Pakistani authors are victorious in transmitting their memo to the overseas readers via code-mixing?

2. Is code-mixing is a marked aspect in postcolonial-literature and how Pakistani English writers marked the native cultures and societal ideals in terms of code-mixing?

\section{Literature Review}

The language plays a very vital role to associate states and inhabitants from each other because it is a technique to isolate the people from one another as a state or a nation. Dialect is meant to converse with one another in either verbal or written form. David Crystal (1985, p.262) affirms that dialect is the most imperative way of communication to develop the incidence of users. Babatunde (2002, p.1) regards language as a mean of existing.

In order to observe and notice the code mixing in a Language, there are no certain norms but it is being observed by native of that one Language because it is the result of incensement in the curiosity and interest of reader towards the literary piece and induces the bibliophile to go through the manuscript. Code-mixing was earliest observed in the works of West African Languages and Ansre (1971) described it as an insertion of diverse chunks of English into the performance of West African Languages in trying to demonstrate the control of English on West African Languages.

Code-mixing is the utilization of one language in relation with another language or the mixing of two or more languages or language diversities in a speech. Hamers and Blanc (1989, p.35) say that code- mixing is the consumption of elements of single language in one more language. They were of the viewpoint that a reallocation of using linguistic units (phrases, clauses and words 
etc.) of one language to another language within a particular sentence is known as code mixing. Diverse instigators have believed that clarity differs when we talk about code-mixing and codeswitching. Lanz (2011) regards code-mixing as a synonym for intra-sentential code switching while Pfaff describes this also for code-mixing and borrowings.

Ardila (2005, p.60-81) affirms that the exchanging between two languages in a particular sentence is called code mixing whereas code switching is not toggling in a sentence rather it is an entire alteration to the second language for an amount of sentences. He is of the view that Code mixing is upon words level but on the other side when we speak about code switching then it is exchange that maneuvers at sentence level and it is mainly common in speaking. However Köppe and Meisel (1995, p.277) utter that code-mixing consists of semantic and pragmatic deviations Moreover Muysken (2000, p.1) describes that code mixing is a deviation amongst the grammatical aspects as well.

\section{Research Methodology}

This study analyzes the features of code-mixing in Pakistani English post-colonial works. I will examine the occurrence of mixing of these Urdu words mainly in the elected genres. Following one novel and short story have been selected as a sample of study.

1. An American Brat by Baspi Sidhwa

2. The Escape by Qaisra Shehraz

These two literary works are from Pakistani English postcolonial -literature as these literary pieces had been written after independence. I have utilized qualitative method to construe and illustrate the results. The words have been taken from elected literary works and then elucidation has been done as a result. In order to analyze accordingly, the occurrence of the repeated words would be composed. For the sake of further elaboration, data would be cataloged into different areas and groups.

Qualitative research has been used to underline the occurrence of mixed-words in these Pakistani English works because it focuses on the results of the qualitative analysis. The data has been analyzed qualitatively. The intellectual representations of these works have been shown with the qualitative analysis. The usage of Urdu words represents many Pakistani lexical features in these literary texts. In the following segments, I will accord this investigation in exhaustive chunk with respect to these leaflets under cram.

\section{Analysis and Discussion on Selected Leaflets}

This segment does not only highlight and discuss the appellations of the native ethnicity but also those appellations which don't have literal correspondent in English Language as well. At several areas, it looks that awareness of the author and writer has become amplified or augmented through the portrayal of cultures, values and language. Moreover compound nouns and verbs have been generally used by the writers through the tool of code mixing because these appellations belong to sundry realms and stand for the cultural norms. By showing close 
association with them through an incandescent way of speech, the author does not only employ the native language but also highlights the culture of native people as well.

\subsection{The Escape by Qaisra Shahraz}

The Escape is written by Qaisra Shahraz. This short story highlights the Diaspora's writing by highlighting the identity issues of immigrants, especially Muslim world with respect to belonging and un-belonging. It also deals with auto biographical elements. In an interview with Claire Chambers (2017, p.102-107) the author herself claims that this short story is very much akin to the writer's father life who was lingering with Back Home and Homeland? Which homeland? In this short story the character of Sameer is the clear portrayal of her father's personality and life. This short story is based on bilingualism and used two Languages of different countries. Short Story lapses among intellectual as well as moral issues and highlights metropolitan and uncivilized concept of society. The words from English and Urdu have also been added.

a) Edibles/ Food Stuff \& Drinks:

\begin{tabular}{|c|c|}
\hline Names & Page Numbers \\
\hline Sewayian ( Three Times) & $1,2,3$ \\
\hline Chana Chat (Three Times) & $1,2,3$ \\
\hline Basmati Rice & 2 \\
\hline Chapatti & 2 \\
\hline Shami Kebabs, Kebabs & 2 \\
\hline Pilau Rice (Two Times) & 2,10 \\
\hline Gajar Halwa (Two Times) & 2,3 \\
\hline Curry & 3 \\
\hline Custard & 5 \\
\hline Lamb Biryani & 5 \\
\hline Chicken Shorba & 5 \\
\hline Keema Lobia & 7 \\
\hline Tabark & 10 \\
\hline Parathas & 10 \\
\hline Kulchas & 10 \\
\hline Lasi & 8 \\
\hline Miranda & 8 \\
\hline
\end{tabular}

b) Mode of Address \& Exclamation:

\begin{tabular}{|c|c|}
\hline Names & Page Number \\
\hline Abu-ji & 2 \\
\hline Velati & 5 \\
\hline Shush! & 2 \\
\hline Babu & 12 \\
\hline Daigmen & 10 \\
\hline
\end{tabular}


c) Abstract \& Feminine Noun:

\begin{tabular}{|c|c|}
\hline Names & Page Number \\
\hline Zakat & 9 \\
\hline Izzat & 12 \\
\hline
\end{tabular}

d) Religion, Prayers \& Mosques:

\begin{tabular}{|c|c|}
\hline Names & Page Number \\
\hline Imam & 1 \\
\hline Allah Pak & 9 \\
\hline Jumma & 1 \\
\hline Traveeh & 1 \\
\hline Hatham & 5 \\
\hline Darul Uloom Masjid & 1 \\
\hline Maki Masjid & 1 \\
\hline
\end{tabular}

e) Places, Shops, Objects \& Money:

\begin{tabular}{|c|c|}
\hline Names & Page Number \\
\hline Eidhi (Three Times) & 2,3 \\
\hline Darul Uloom Centre & 1 \\
\hline Sanam Sweet Shop & 2 \\
\hline Anarkali Bazar & 4 \\
\hline Mall Road & 4 \\
\hline Motorcycle & 6 \\
\hline Minar Tree & 6 \\
\hline Trafalgar & 6 \\
\hline Darwin Mill & 7 \\
\hline Kothi & 8 \\
\hline Bethak & 8 \\
\hline Phone & 9 \\
\hline Data Gunj Darbar & 10 \\
\hline Darbar (Three Times) & 10 \\
\hline
\end{tabular}

f) Festivals, Festive \& Welcome Greetings:

\begin{tabular}{|c|c|}
\hline Names & Page Number \\
\hline Eid Mubarak & 1 \\
\hline Bisnillah! Bismillah! & 8 \\
\hline Ramdhan & 1 \\
\hline
\end{tabular}




\section{Eid ul Fitr}

3

g) Clothes and Newspaper:

\begin{tabular}{|c|c|}
\hline Names & Page Number \\
\hline Bengali Sari & 1 \\
\hline Shalwar kameez (Two Times) & 2 \\
\hline Shervani, Sherwanis & 2 \\
\hline Ghraras & 2 \\
\hline Lenghas & 2 \\
\hline Dupattas & 2 \\
\hline The Daily Jang & 2 \\
\hline
\end{tabular}

h) Local Names \& Country:

\begin{tabular}{|c|c|}
\hline Names & Page Number \\
\hline Samir & 1 \\
\hline Manzoor & 1 \\
\hline Maqbool & 2 \\
\hline Rahel & 3 \\
\hline Mehnaz & 3 \\
\hline Roxanna & 4 \\
\hline Mina & 6 \\
\hline Idi Amin & 8 \\
\hline Banu & 11 \\
\hline Ibrahim & 11 \\
\hline Velat, Velat & 7,8 \\
\hline
\end{tabular}

In this short story a small number of code-mixed words have been originated. In his short story main semantic context relates to Pakistani culture and religion Islam. The words imam, Data Gunj Darbar; Data Sahib is the most pious person in Islamic context and consider as wali ullah. Addressing modes have also been used normally. For instance, Abu-ji, Velati and other mode of addressing have been utilized in this genre. The attire items have also been used in the whole of the short story. All the dresses relate to Pakistani tradition such as kurta, shalwar, kamize, Shervani. It illustrates the custom and culture of Pakistani Islamic country. The majority of the attires is of females and has used to cover the whole body. It belongs to Islamic traditions just like the word dupatta is exercise to cover up the whole head but in British culture it considers as the traditional notion to be dressed in a dupatta.

In this short story the most of terms belong to the Islamic traditions. The mostly used term is "Imam" that reflects a person who fight for the spiritual purposes. The utilization of all these terms is to demonstrate the culture and values without giving translations. The usage of these words in English highlights a factual picture of the Pakistani culture and ideology by supporting the religious expressions in term of prayer (Allah Pak, Traveeh, Ramdhan and Hatham as well. 
Moreover, the word Tabaruk has been used in this short story which is considered Pious and good food in Islam.

\subsection{An American Brat by Bapsi Sidhwa}

This novel highlights the fifty four circumstantial areas that have been given by Baumgardner et al. However the researcher has pointed out a small number of textual areas that are being used in this Pakistani English novel. In this novel in the light of semantic framework a few words and their textual area have been observed in the light of semantic framework which is twenty six in number set by Kachru. These types of code mixing have been classified by this model, so it can be straightforward for the researcher to point out the text-words and evaluation. In this novel Pakistani semantic contexts and occurrence of words have been figured out and are discussed in detail.

a) Concepts, Condiments, Residences \& Places

\begin{tabular}{|c|c|}
\hline Names & Page Number \\
\hline Shonour & 66 \\
\hline Izzat & 66,111 \\
\hline Paans & 201 \\
\hline Easop-gol & 201 \\
\hline Bunglow & 34 \\
\hline Haveli & 42 \\
\hline Jhuggees & 238,239 \\
\hline Landa bazaar & 13 \\
\hline
\end{tabular}

b) Edibles, Health \& Prayers

\begin{tabular}{|c|c|}
\hline Names & Page Number \\
\hline Tandrosti & 41 \\
\hline Aa-meen & 46 \\
\hline Roti & 44 \\
\hline Dhan-dar & 44 \\
\hline Dal & 112 \\
\hline Dal, rice & 142 \\
\hline Basmati & 263 \\
\hline Pakoras & 36,38 \\
\hline Patia & 114,262 \\
\hline Dhanask & 114 \\
\hline Lentils & 114 \\
\hline Pora & 296 \\
\hline
\end{tabular}


UNIVERSITY OF CHITRAL JOURNAL OF LINGUISTICS AND LITERATURE

VOL. 3 | ISSUE II | JULY - DEC | 2019

\section{c) Psychological Terms \& Racism}

\begin{tabular}{|c|c|}
\hline Names & Page Number \\
\hline Gora complex & 26,147 \\
\hline Desi (Eight Times) & $73,74,101,102,103,199,230$ \\
\hline Gora & 141 \\
\hline Gora-chittas & 271 \\
\hline Parjat & 84 \\
\hline
\end{tabular}

d) Religions \& Religious Tags

\begin{tabular}{|c|c|}
\hline Names & Page Number \\
\hline Mullahs (Seven Times) & $11,13,162,282$ \\
\hline Maulvi (Four Times) & 10 \\
\hline Burqas & 19 \\
\hline Sufi & 21,48 \\
\hline Allah & 91 \\
\hline Mujahahideen & 19 \\
\hline Guduwaras & $40,41,278$ \\
\hline Agyari (Six Times) & $40,41,47,278,317$ \\
\hline Atash (Six Times) & $41,164,165,278,317$ \\
\hline Kusti (Nine Times) & $164,220,278,317$ \\
\hline Sudras (Six Times) & 252,254 \\
\hline Bhagwan (Three Times) & 204,293 \\
\hline Navjote (Two Times) & 257 \\
\hline Adarnee & 257 \\
\hline Madasara & \\
\hline
\end{tabular}

e) Slogans, Social Gatherings, Systems \& Organizations

\begin{tabular}{|c|c|}
\hline Names & Page Number \\
\hline "Roti, Kapre, Makan" & 21 \\
\hline Zindabad & 21 \\
\hline Mushairas & 311 \\
\hline
\end{tabular}


UNIVERSITY OF CHITRAL JOURNAL OF LINGUISTICS AND LITERATURE

VOL. 3 | ISSUE II | JULY - DEC | 2019

\begin{tabular}{|c|c|}
\hline Mehfil & 311 \\
\hline Khandan & 277 \\
\hline Lesson-Wallas (Three Times) & 111 \\
\hline Taxi-Wallas & 194 \\
\hline Bhagwan-Walla & 254 \\
\hline Anjumans (Four Times) & $262.288,299$ \\
\hline Parsee Panchayat & 287 \\
\hline
\end{tabular}

f) Negative Description, Gender \& Political Systems

\begin{tabular}{|c|c|}
\hline Names & Page Number \\
\hline Zina (Two Times) & 236,237 \\
\hline Gondas (Three Times) & $11,135,223$ \\
\hline Fundos (Two Times) & 12,305 \\
\hline Uloo & 68 \\
\hline Sala badmash & 196 \\
\hline Guru & 210 \\
\hline Police-thana & 106 \\
\hline Raj (Three Times) & $36,37,196$ \\
\hline Heejras (Four Times) & 78,79 \\
\hline
\end{tabular}

g) Adjectives, Articles, Buildings, Art Forms \& Occupations

\begin{tabular}{|c|c|}
\hline Names & Page Number \\
\hline Khandani & 222 \\
\hline Lathi & 282 \\
\hline Ghazal (Two Times) & 311 \\
\hline Quawali & 19 \\
\hline Veranda & 10,16 \\
\hline Ayah (Seventeen Times) & $11,13,18,23,26,27,28,29,30,31,32,33,43,162,178$ \\
\hline
\end{tabular}




\section{h) Descriptive Labels, Fabrics, Measurement, Money \& Occupation}

\begin{tabular}{|c|c|}
\hline Name & Page Number \\
\hline Boochimai (Six Times) & $69,78,133,222$ \\
\hline Afeemi (Two Times) & 84,127 \\
\hline Memsahib & 107 \\
\hline Madam-ni-ma & 69 \\
\hline General sahib & 122 \\
\hline Mudums & 272 \\
\hline Shatoose & 21 \\
\hline Nylon-satin kamize & 74 \\
\hline Thaans (Two Times) & 220 \\
\hline Paisa & 134 \\
\hline Doria & 50 \\
\hline
\end{tabular}

i) Kinship Terms, Law, Marriage \& Modes of Addressing

\begin{tabular}{|c|c|}
\hline Names & Page Numbers \\
\hline Kaka (Three Times) & 50,134 \\
\hline Kaki & 134 \\
\hline Baap (Two Times) & 192,197 \\
\hline Hadood ordinance & 236 \\
\hline Federal shariat & 236 \\
\hline The adarenee & 297 \\
\hline Jana & 14 \\
\hline Baijee & 33 \\
\hline Jee (Nine Times) & $52,53,122,223$ \\
\hline Baba (Four Times) & $86,101,192,240$ \\
\hline Yaar (Three Times) & 97,196 \\
\hline Bibi & 173 \\
\hline Begum Bhutto & 175 \\
\hline
\end{tabular}


UNIVERSITY OF CHITRAL JOURNAL OF LINGUISTICS AND LITERATURE

VOL. 3 | ISSUE II | JULY - DEC | 2019

\section{j) Accessories \& Celebrations}

\begin{tabular}{|c|c|}
\hline Names & Page Number \\
\hline Burqas & 10 \\
\hline Sagan & 44 \\
\hline Pyjama (Two Times) & 10,35 \\
\hline Shawl (Ten Times) & 244 \\
\hline Kashmiri Shawl & $10,16,20,21,33,34,157,242$ \\
\hline Sari ( Thirty Five Times) & $10,15,17,29,31,106,173,174,177,178,204,221$, \\
& $222,244,252,272,275,278,297,298,299,300,303,304$ \\
\hline Sari-blouse (Four Times) & $10,13,31,192$ \\
\hline Dopattas & 11 \\
\hline Lungi Pyjamaed & 13 \\
\hline Cholis & 21 \\
\hline Kapra & 36 \\
\hline Cummerbund & $31,41,164,165,278,304$ \\
\hline Kusti (Eleven Times) & $31,164,278,317$ \\
\hline Sudras (Seven Times) & 42,122 \\
\hline Shalwar-kamize (Two Times) & 42,72 \\
\hline Cashmere shalwar- kamize (Two Times) & 43,297 \\
\hline Tanchoi Sari (Three Times) & $43,252,304$ \\
\hline Palloo (Four Times) & 74,122, \\
\hline Kamiez (Two Times) & $74,192,196,242$, \\
\hline Shalwar (Four Times) & 106,217 \\
\hline Dhoties (Two Times) & 192 \\
\hline Khaki & 248 \\
\hline Feta & 297,298 \\
\hline Sari Sets (Two Times) & 303 \\
\hline Sari Scarf & \\
\hline & \\
\hline & \\
\hline & \\
\hline
\end{tabular}

It is obvious from the study that the greater parts of words are the part of arty milieu. For instance accessories are most of the attire words that are meant to women because attire for men does not reflect much diversity that has been changed by Western clothing just like blouses, pants and suits etc. Important parts of Muslim women dresses have also been shown like dopattas, burkas, shawl and etc. These accessories with respect to cultural terms are atypical for English (Non-Muslims Community) bookworms, because such clothe is not used in their culture to cover head. In this novel there is a wider discussion on Pakistani outfits versus Western outfits just like (sari-blouse, kurta-shirt, shalwar-and-shirt outfit and Sari-sets). These Pakistani attires have been a big reason behind migration to abroad.

The main objective of the author is to emphasize on the edifying ideals of Pakistan by using local words more successfully. These words not only emphasize on the cultural images but also deal with the values of culture, prevailing in a particular society as well. Moreover the analysis also 
highlights that particular clothes are used for particular occasions. For instance demise, marriage ceremony, quiescent, and travelling are also used to explain the particular religious, foreign, local and cultural types. For example, tanchoi sari (p. 43) and cotton sari (p. 29) are particular examples of the same clothing, mentioned in the novel as well. Sari is most often used clothing accessory in the novel for forty-three times and it is usually utilized by middle and upper class women as well.

The novelist has manipulated such word like 'IZZAT' which have an English equivalent like 'RESPECT' but she used this word strengthen the meaning of her own culture through the impact of language. So, theories and dresses with respect to her own Pakistan cultural values have been proficiently described by Bapsi Sidhwa in this novel. Many times in this novel she uses the local words from her own native language $U R D U$ in order to enhance the impact of Urdu Language on the reader's psyche just like choop kar (p. 57) and never discriminate Pakistani culture in this novel through the proper use of 'URDU WORDS' from her own culture context as well.

\section{Conclusion}

This research article has acknowledged that all languages have their own weight and function amidst its own speaker and reader by undermining the very fact of submissiveness and less weight age, because code-mixing in English Pakistani Literature written by Pakistani authors has been discovered to an immense range. While writing their writings in Pakistani English Context the writers not only humiliated the local differences, comparatively they have also accentuated the concern of Pakistani English as English Language which is usually unsuccessful to accomplish the emotional obligations of local people. In order to fulfill the rhetorical divergence of intellectual ideas in English, these borrowings from the local Languages are used by Pakistani writers in their writings as well and the purpose of this code mixing is not to represent the English as an inferior type. The author also comes to an end that the weight of local Languages and indication of a question mark upon dialect has also been meant through the proper use of local words. This research work also focuses on the words of daily use without having any alternate in English, which is also a field of study for the British people because modern motifs have been engaged in stories and novels with respect to code mixing methods in English literature.

\section{References}

Altarriba, Dana M Basnight-Brown and Jeanette. "Code-switching and code-mixing in bilinguals: Cognitive, developmental, and empirical approaches." ResearchGate.net (2007).

Awan, Abdul Ghafoor, Muhammad Tariq Ayub and Sobia Suleman, Nazia Suleman, Aneesul Hassan. "Analysis of Code-Mixing in Pakistani English Post- Colonial Novels." Global Journal of Management and Social Sciences, Vol 2 (4) (2016): 57-76. 
Ayeleru, Babatunde. "Linguistics Innovation in the New West African Europhone Novel: Between Interlanguage and Indigenization." Nigeria: University of Ibadan (2011).

Balnc, Josiane F. Hamers And Michel H.A. "Bilinguaility And Bilinguailism." The Pitt Building, UK: Trumphington Street, Cambridge CB2 1RP (1989).

Bandia, P. "Code-Swithching and Code-Mixing in African Creative Writing." Some Insights for Translation Studies (1996): 139-153.

Baumgardner, R. J. Eds. "The English Language in Pakistan." Oxford: Oxford University Press (1993).

Claire Chambers, Qaisra Shahraz. "Qaisra Shahraz in Interview with Claire Chambers." $\underline{\text { IIUM }}$ Journal of English Language and Literature (2017): 102-109.

Lanz Vallejo, L. (2011). El cambio de código español-inglés como creatividad lingüística presentación de la imagen en tweets escritos por tijuanenses.

Dr. Muhammad Fareed Dar, Huma Akhtar And Hamna Khalid. "Code-Switching in Pakistani English Language Classrooms: Perceptions of English Language Teachers." JSSIR: Volume 3, Number 2 (2014): 107-120.

Kachru, B. B. "The Indianization of English: The English Language in India." Delhi: Oxford University Press (1983).

Meisel, Jürgen M. "Studies in Second Language Acquisition: CODE-SWITCHING IN YOUNG BILINGUAL CHILDREN: The Acquisition of Grammatical Constraints." Cambridge University Press, Vol. 16, No. 4 (1994): 413-439.

Shahraz, Qaisra. The Escape. qaisrashahraz.com, 2013.

Sidhwa, B. An American Brat. Penguin books, 1994.

Sidhwa, B. "New English creative writing: A Pakistani writer's perspective." (1993).

Talib, I. S. The Language Of Postcolonial Literature. New York: New York Routledge, 2002.

Wardough, Ronald. An Introduction To Sociolinguistics. New York: New York Basil, 1986.

Ardilla. "Spanglish: an anglicized Spanish dialect." Hispanic Journal of Behavioral (2005): 6081. Literature, Pakistan. This article is an open access article distributed under the terms and conditions of the Creative Commons Attribution (CC BY) (http://creativecommons.org/licenses/by/4.0/). 
UNIVERSITY OF CHITRAL JOURNAL OF LINGUISTICS AND LITERATURE

VOL. 3 | ISSUE II | JULY - DEC | 2019

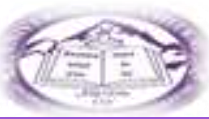

ISSN (E): 2663-1512, ISSN (P): 2617-3611 